Reprod. Nutr. Dévelop., 1985, 25 (3), 495-504.

\title{
In vivo milk digestion in the calf abomasum. III. Amino acid compositions of the digesta leaving the abomasum
}

\author{
Mireille YVON, J.-P. PÉLISSIER ( $\left.{ }^{1}\right)$, P. GUILLOTEAU $\left({ }^{*}\right)$, R. TOULLEC $\left({ }^{*}\right)$ \\ Laboratoire de Biochimie et Technologie Laitières, \\ I.N.R.A., 78350 Jouy-en-Josas, France. \\ $\left.{ }^{*}\right)$ Station de Recherches sur les jeunes Bovins, I.N.R.A., \\ 65, Route de St-Brieuc, 35042 Rennes Cedex, France.
}

Summary. Calves were fed five different test meals : whole milk, skim milk, $3 \%$ whole casein solution, $3 \%$ whole casein in simulated milk ultrafiltrate, and whey. The digesta leaving the abomasum before feeding and during the first 7 postprandial hours were collected by fractions. After precipitation with $12 \%$ TCA, the amino acid compositions of the sediments and the supernatants were determined and compared by multivariate analysis.

The composition of prefeeding digesta was similar to that of gastric juice. When the calves were fed the two casein diets, the amino acid composition of the sediments changed little with time. In contrast, the changes observed in the composition of the supernatants suggested rapid abomasal emptying of caseino-macro peptide. With the whey diet, it was not possible to evidence more rapid hydrolysis or abomasal emptying of any particular whey protein.

During the first $10 \mathrm{~min}$ following the ingestion of whole or skim milk, the amino acid composition of the sediment was close to that of milk protein. Immediately afterwards, the composition of the sediment was similar to that of whey protein. Thereafter, the composition of the sediment became more like that of casein and almost reached that of casein during the 7th hour. The amino acid composition of the supernatant was similar to that obtained with the casein diets ; this fact suggests that the small peptides produced by proteolysis in the abomasum originated more from casein than from whey proteins.

\section{Introduction.}

In the preruminant calf, the first step of protein digestion occurs in the abomasum. In a previous work (Pélissier et al., 1983), we studied gastric emptying in preruminant calves fed test meals of milk, whey or whole casein solutions. In other reports (Yvon et al., 1984a,b), peptide products, which appeared in the proximal duodenum of these calves at different times after the

(1) All correspondance to : J.-P. Pélissier, I.N.R.A., Laboratoire de Biochimie et Technologie Laitières, 78350 Jouy-en-Josas, France. 
test meals, were characterized by electrophoresis, isoelectric focusing and SDS pore gradient gel electrophoresis.

The amino acid compositions of whole casein and total whey proteins are different. Thus, the amino acid composition of the digesta leaving the abomasum of preruminant calves should vary depending on whether the diet contains casein solutions, whey or milk.

Milk coagulation or casein precipitation at acid $\mathrm{pH}$, as well as milk protein proteolysis in the stomach, should modify the amino acid composition of the digesta leaving the abomasum at different times after the ingestion of the diets. In the present work, we have studied the amino acid composition of peptide products arriving in the proximal duodenum of calves fed whole milk, skim milk, whey or casein solutions.

\section{Material and methods.}

Animals, diets and experimental design. - The feeding and collection procedures used for the calves have been described previously (Pélissier et al., 1983 ; Yvon et al., 1984a). Two animals, fitted with a duodenal reentrant cannula received $5-\mathrm{kg}$ test meals. All the digesta leaving the stomach during the first $7 \mathrm{~h}$ after the meal were collected by fractions : for 10 min during the first hour, for 15 min during the second hour, and for 30 during the remaining time. A sample was also collected just before feeding.

Five diets were prepared with the same milk : whole milk (A); skim milk (B) ; $3 \%$ whole casein solution in water (C) ; $3 \%$ whole casein solution in simulated milk ultrafiltrate (D) (Jenness and Koops, 1962); whey (E). Diets A, B, C and D were given three times and diet $\mathrm{E}$ only one time.

Analysis. - Each sample was precipitated with trichloracetic acid (TCA) to a $12 \%$ final concentration and centrifuged at $2,000 \times \mathrm{g}$ for $20 \mathrm{~min}$. After homogenization in water, the sediment was extracted 10 times with an equal volume of diethyl ether to eliminate the TCA, and then lyophilized.

The sediments, supernatants and diets were hydrolized in $1.5 \mathrm{ml}$ of $5.7 \mathrm{~N} \mathrm{HCl}$ at $110^{\circ} \mathrm{C}$ in evacuated sealed glass tubes for $24 \mathrm{~h}$ and then analysed with a Multichrom amino acid analyser (Beckman, Munchen, W. Germany).

The determinations of 17 amino acids were compared by principal component statistical analysis (Hill, 1974). With this method, each sample was considered as a point in a 17 dimensional space with 17 variables (the \% of each of the 17 amino acids detected by amino acid analysis). This initial pattern was reduced to a bidimensional space in which the two axes (called factors) were not correlated. The new axes were interpreted in relation to the former variables by computing the loading of each variable on these axes. $70 \%$ of the information contained in the data was visualized on this plane. The smaller the distance between the two points characterizing the two samples, the more similar were the two samples. 


\section{Results and discussion.}

Diet composition. - In our analytical conditions, there were three major differences between the amino acid composition of the diets (table 1). Compared with whey, casein had lower Asx $(6.9 \%$ of the amino acid vs $10.6 \%)$ and cysteine $(0.2 \%$ vs $2.2 \%)$ concentrations and a higher proline concentration $(11.6 \%$ vs $5.5 \%)$.

Prefeeding digesta. - Before the calves were given a test meal, they were starved for $24 \mathrm{~h}$. The last meal given was milk which had been sodium-citrated to prevent the formation of a firm clot. Therefore, the abomasum of the calves was probably free of food residues, and the digesta collected before feeding were mainly of endogenous origin, as shown by their amino acid composition (table 1) which was similar to that of calf gastric juice (Guilloteau et al., 1983). The higher Gly concentration of the digesta could be due to a slight reflux of bile since this amino acid constitutes about $95 \%$ of bile total amino acids (Juste, 1982).

Casein diet digesta. - With " casein " diets C and D, the proportions of Asx, Pro and Cys in the sediments did not vary much from one time to another, remaining relatively close to those determined in casein. The proportions of Thr, Glx, Ala, Ile, Leu, Lys and Arg in the supernant approached the proportion observed in casein when digestion time increased.

\section{TABLE 1}

Amino acid compositions of diets and digesta collected before feeding (moles per 100 moles)

\begin{tabular}{ccccccc}
\hline & \multicolumn{3}{c}{ Diets } & & & Prefeeding digesta \\
\cline { 2 - 6 } & Whole casein & Whole milk & Whey & Sediment & Supernatant & Gastric juice (*) \\
\hline Asx & 6.9 & 7.5 & 10.6 & 9.2 & 9.9 & 9.9 \\
Thr & 4.7 & 4.7 & 5.5 & 6.4 & 6.2 & 6.8 \\
Ser & 7.0 & 6.9 & 6.0 & 6.7 & 6.6 & 7.7 \\
Glx & 18.5 & 17.8 & 14.8 & 10.6 & 10.7 & 1.7 \\
Pro & 11.6 & 10.7 & 5.5 & 4.1 & 6.2 & 7.4 \\
Gly & 3.1 & 3.3 & 4.1 & 10.9 & 11.3 & 6.8 \\
Ala & 4.5 & 4.9 & 6.9 & 7.3 & 6.6 & 1.6 \\
Cys & 0.2 & 0.5 & 2.2 & 1.1 & 2.1 & 6.9 \\
Val & 7.3 & 7.1 & 5.3 & 6.1 & 6.2 & 0.8 \\
Met & 2.6 & 2.2 & 2.5 & 2.0 & 0.2 & 4.2 \\
He & 5.0 & 4.9 & 4.9 & 5.4 & 3.4 & 8.4 \\
Leu & 9.0 & 9.9 & 11.6 & 8.7 & 8.1 & 4.6 \\
Tyr & 2.8 & 3.1 & 3.5 & 2.7 & 5.2 & 3.4 \\
Phe & 4.0 & 4.2 & 4.0 & 5.4 & 5.0 & 2.3 \\
His & 2.4 & 2.4 & 1.9 & 2.1 & 2.1 & 4.3 \\
Lys & 7.7 & 7.3 & 8.7 & 6.7 & 6.6 & 4.7 \\
Arg & 2.7 & 2.5 & 2.1 & 4.5 & 3.3 & \\
\hline
\end{tabular}

(*) Guilloteau et al. (1983). 
As the casein diets did not coagulate but were precipitated at acid $\mathrm{pH}$, they displayed particular gastric emptying kinetics. At around $120 \mathrm{~min}$, the major part of the products leaving the abomasum corresponded to slightly or nonproteolysed casein (Yvon et al., 1984a). During this time, only a little more than $10 \%$ of the ingested $N$ reached the duodenum (Pélissier et al., 1983). In these conditions, the largest part of $\mathrm{N}$ left the abomasum in a proteolysed form.

With the two " casein " diets $\mathrm{C}$ and $\mathrm{D}$, around $30 \%$ of the ingested $\mathrm{N}$ was emptied during the first 7 postprandial hours, as with the milk diets (Pélissier et al., 1983). With diet $C$, the lle : Leu ratio was much higher in the supernatant collected $10-20$ min after feeding than in the casein (2.3 vs 0.5$)$ but later, this ratio was similar in the supernatant and the casein (table 2). The concentration was higher and His, Arg, Tyr and Phe concentrations lower in the 10 to 20-min sample than in later samples. A similar trend was observed with diet $D$ and to a lesser extent with diets $A$ and $B$. Caseino-macro peptide contains 7 times more lle than Leu ; it is very rich in Thr and devoid of Tyr, Phe, His and Arg (Mercier et al., 1972). This peptide is partially soluble in $12 \%$ TCA and could constitute a large part of the supernatant obtained soon after feeding the four diets containing casein.

Whey diet digesta. - With the " whey " diet (E), there was little or no change with time after the meal. The amino acid composition of the sediment remained close to that of whey proteins. The profile of amino acid composition did not show whether any particular whey protein was hydrolysed or left the

TABLE 2 (continued)

Amino acid composition of some samples collected with the different diets (moles per 100 moles)

\begin{tabular}{|c|c|c|c|c|c|c|c|c|c|c|c|c|}
\hline & \multicolumn{6}{|c|}{ Whole milk } & \multicolumn{6}{|c|}{ Skim milk } \\
\hline & \multicolumn{3}{|c|}{ Sediment } & \multicolumn{3}{|c|}{ Supernatant } & \multicolumn{3}{|c|}{ Sediment } & \multicolumn{3}{|c|}{ Supernatant } \\
\hline & $\begin{array}{c}10-20 \\
\min \end{array}$ & $\begin{array}{c}2 \mathrm{~h}- \\
2 \mathrm{~h} 30\end{array}$ & $\begin{array}{c}6 h- \\
6 h 30\end{array}$ & $\begin{array}{c}10-20 \\
\min \end{array}$ & $\begin{array}{c}2 h \\
2 h 30\end{array}$ & $\begin{array}{c}6 h- \\
6 h 30\end{array}$ & $\begin{array}{c}10-20 \\
\min \end{array}$ & $\begin{array}{c}2 \mathrm{~h}- \\
2 \mathrm{~h} 30\end{array}$ & $\begin{array}{c}6 h- \\
6 \text { h } 30\end{array}$ & $\begin{array}{c}10-20 \\
\min \end{array}$ & $\begin{array}{c}2 \mathrm{~h}- \\
2 \mathrm{~h} 30\end{array}$ & $\begin{array}{c}6 h- \\
6 h 30\end{array}$ \\
\hline Asx & 9.6 & 10.4 & 8.6 & 8.1 & 9.6 & 9.7 & 9.7 & 9.1 & 7.1 & 9.6 & 8.3 & 7.9 \\
\hline Thr & 6.2 & 5.3 & 4.3 & 7.1 & 6.9 & 4.8 & 6.6 & 5.7 & 4.6 & 9.3 & 7.9 & 5.2 \\
\hline Ser & 7.1 & 5.8 & 5.9 & 6.5 & 8.0 & 8.0 & 6.7 & 6.5 & 6.8 & 6.5 & 7.5 & 7.3 \\
\hline Glx & 16.1 & 14.5 & 16.9 & 14.8 & 17.5 & 17.9 & 15.3 & 15.6 & 17.9 & 16.5 & 15.2 & 17.0 \\
\hline Pro & 8.2 & 8.2 & 11.4 & 11.5 & 9.6 & 10.2 & 7.3 & 8.8 & 11.9 & 9.3 & 9.9 & 11.4 \\
\hline Gly & 3.6 & 3.7 & 3.4 & 4.0 & 3.4 & 3.4 & 4.0 & 3.8 & 3.6 & 5.1 & 3.8 & 3.8 \\
\hline Ala & 5.7 & 5.9 & 4.7 & 5.3 & 5.5 & 5.1 & 6.4 & 5.9 & 4.6 & 6.7 & 5.9 & 5.3 \\
\hline Cys & 1.5 & 2.2 & 0.9 & 0.3 & 0.0 & 0.0 & 2.3 & 1.8 & 0.7 & 0.2 & 0.0 & 0.0 \\
\hline Val & 6.5 & 6.6 & 7.4 & 7.5 & 5.9 & 5.5 & 6.7 & 6.8 & 7.5 & 6.3 & 6.6 & 6.4 \\
\hline Met & 1.7 & 1.0 & 1.3 & 1.0 & 0.7 & 0.5 & 1.9 & 2.2 & 2.9 & 0.2 & 1.6 & 1.7 \\
\hline Ile & 4.9 & 4.7 & 4.9 & 5.2 & 4.9 & 4.1 & 5.5 & 5.1 & 4.8 & 5.1 & 5.3 & 4.0 \\
\hline Leu & 10.2 & 11.3 & 9.8 & 6.5 & 7.7 & 9.7 & 10.2 & 10.5 & 8.7 & 5.5 & 7.4 & 9.6 \\
\hline Tyr & 3.1 & 3.4 & 3.4 & 6.4 & 5.2 & 5.7 & 1.7 & 1.8 & 1.8 & 5.1 & 3.9 & 3.6 \\
\hline Phe & 3.3 & 4.0 & 3.8 & 5.1 & 4.1 & 4.1 & 3.5 & 3.9 & 4.3 & 4.4 & 4.6 & 4.3 \\
\hline $\mathrm{His}$ & 1.9 & 2.2 & 2.6 & 2.1 & 1.5 & 1.4 & 1.8 & 2.1 & 2.6 & 1.4 & 2.0 & 1.8 \\
\hline Lys & 7.8 & 8.1 & 7.6 & 6.5 & 6.7 & 6.9 & 8.1 & 8.1 & 7.7 & 6.3 & 7.5 & 7.4 \\
\hline Arg & 2.3 & 2.5 & 2.8 & 2.1 & 2.7 & 2.9 & 2.3 & 2.4 & 2.7 & 2.4 & 2.7 & 3.3 \\
\hline
\end{tabular}


TABLE 2 (p. 2) (continued)

\begin{tabular}{|c|c|c|c|c|c|c|c|c|c|c|c|c|}
\hline & \multicolumn{6}{|c|}{ Whole casein in water } & \multicolumn{6}{|c|}{ Whole casein in mineral solution } \\
\hline & \multicolumn{3}{|c|}{ Sediment } & \multicolumn{3}{|c|}{ Supernatant } & \multicolumn{3}{|c|}{ Sediment } & \multicolumn{3}{|c|}{ Supernatant } \\
\hline & $\begin{array}{c}10-20 \\
\min \end{array}$ & $\begin{array}{c}2 h- \\
2 h 30\end{array}$ & $\begin{array}{l}6 \mathrm{~h}- \\
6 \mathrm{~h} 30\end{array}$ & $\begin{array}{c}10-20 \\
\min \end{array}$ & $\begin{array}{c}2 \mathrm{~h} \\
2 \mathrm{~h} 30\end{array}$ & $\begin{array}{c}6 \mathrm{~h}- \\
6 \mathrm{~h} 30\end{array}$ & $\begin{array}{c}10-20 \\
\min \end{array}$ & $\begin{array}{c}2 \mathrm{~h}- \\
2 \mathrm{~h} 30\end{array}$ & $\begin{array}{c}6 \mathrm{~h}- \\
6 \mathrm{~h} 30\end{array}$ & $\begin{array}{c}10-20 \\
\min \end{array}$ & $\begin{array}{c}2 \mathrm{~h}- \\
2 \mathrm{~h} 30\end{array}$ & $\begin{array}{c}6 \mathrm{~h}- \\
6 \mathrm{~h} 30\end{array}$ \\
\hline Asx & 7.7 & 7.1 & 7.2 & 8.8 & 9.1 & 7.7 & 8.2 & 8.4 & 6.6 & 9.4 & 8.9 & 8.8 \\
\hline Thr & 4.6 & 4.6 & 5.1 & 12.9 & 6.0 & 4.9 & 4.4 & 4.9 & 4.4 & 9.1 & 4.6 & 4.6 \\
\hline Ser & 7.4 & 7.2 & 6.9 & 9.3 & 7.8 & 7.5 & 6.6 & 6.9 & 6.0 & 8.5 & 7.6 & 8.3 \\
\hline $\mathrm{Glx}$ & 19.1 & 17.9 & 18.1 & 13.8 & 16.6 & 18.4 & 18.8 & 18.4 & 16.9 & 15.6 & 18.2 & 20.0 \\
\hline Pro & 11.8 & 13.1 & 11.5 & 12.5 & 11.8 & 11.0 & 11.6 & 12.4 & 14.0 & 12.8 & 10.8 & 10.3 \\
\hline Gly & 3.1 & 3.6 & 3.6 & 3.7 & 3.6 & 3.8 & 3.1 & 3.5 & 3.1 & 3.3 & 3.1 & 3.2 \\
\hline Ala & 4.3 & 4.4 & 4.5 & 7.0 & 5.8 & 5.2 & 4.3 & 4.1 & 4.4 & 5.7 & 5.3 & 4.8 \\
\hline Cys & 0.0 & 0.0 & 0.0 & 0.0 & 0.0 & 0.0 & 0.0 & 0.3 & 0.5 & 0.0 & 0.0 & 0.0 \\
\hline $\mathrm{Val}$ & 7.2 & 8.1 & 7.2 & 7.8 & 6.5 & 6.3 & 7.4 & 8.1 & 8.0 & 5.8 & 5.4 & 5.2 \\
\hline Met & 1.3 & 1.4 & 2.3 & 0.3 & 0.2 & 2.3 & 0.9 & 1.1 & 2.4 & 1.0 & 0.4 & 0.6 \\
\hline $\mathrm{He}$ & 4.5 & 4.8 & 4.4 & 7.6 & 5.0 & 4.4 & 4.9 & 4.7 & 4.7 & 5.7 & 3.9 & 4.2 \\
\hline Leu & 8.8 & 8.9 & 8.9 & 3.4 & 9.3 & 10.3 & 9.3 & 7.9 & 8.6 & 6.1 & 10.5 & 9.9 \\
\hline Tyr & 3.9 & 1.4 & 3.6 & 1.8 & 2.1 & 1.6 & 4.2 & 3.4 & 3.9 & 3.7 & 5.2 & 5.3 \\
\hline Phe & 4.0 & 4.5 & 4.3 & 3.0 & 3.9 & 4.3 & 4.0 & 4.1 & 4.1 & 4.2 & 4.3 & 3.6 \\
\hline $\mathrm{His}$ & 2.3 & 2.7 & 2.7 & 0.9 & 1.7 & 1.8 & 2.4 & 2.4 & 2.1 & 0.9 & 1.4 & 1.3 \\
\hline Lys & 7.2 & 7.4 & 7.1 & 6.0 & 7.2 & 7.4 & 7.2 & 7.0 & 7.7 & 6.3 & 6.8 & 7.2 \\
\hline Arg & 2.7 & 2.8 & 2.5 & 1.2 & 3.5 & 3.1 & 2.8 & 2.4 & 2.7 & 1.8 & 3.6 & 2.8 \\
\hline
\end{tabular}

TABLE 2 (p. 3)

\begin{tabular}{|c|c|c|c|c|c|c|}
\hline & \multicolumn{6}{|c|}{ Whey } \\
\hline & \multicolumn{3}{|c|}{ Sediment } & \multicolumn{3}{|c|}{ Supernatant } \\
\hline & $\begin{array}{c}10-20 \\
\min \end{array}$ & $\begin{array}{c}2 \mathrm{~h}- \\
2 \mathrm{~h} 30\end{array}$ & $\begin{array}{c}6 \mathrm{~h}- \\
6 \mathrm{~h} 30\end{array}$ & $\begin{array}{c}10-20 \\
\min \end{array}$ & $\begin{array}{c}2 \mathrm{~h} \\
2 \mathrm{~h} 30\end{array}$ & $\begin{array}{c}6 \mathrm{~h}- \\
6 \mathrm{~h} 30\end{array}$ \\
\hline As $x$ & 10.3 & 10.6 & 10.2 & 11.2 & 11.3 & 11.8 \\
\hline Thr & 6.1 & 6.1 & 5.8 & 5.5 & 6.2 & 8.0 \\
\hline Ser & 6.0 & 6.3 & 5.7 & 6.9 & 7.6 & 8.5 \\
\hline $\mathrm{Glx}$ & 14.3 & 14.5 & 13.2 & 14.7 & 14.2 & 14.5 \\
\hline Pro & 5.8 & 5.6 & 7.0 & 5.8 & 6.0 & 4.9 \\
\hline Gly & 3.8 & 3.9 & 4.1 & 8.9 & 7.7 & 6.3 \\
\hline Ala & 6.9 & 7.1 & 7.5 & 7.9 & 6.7 & 6.7 \\
\hline Cys & 2.9 & 2.3 & 3.4 & 0.0 & 0.0 & 0.7 \\
\hline Val & 6.7 & 6.5 & 6.6 & 5.7 & 5.7 & 6.9 \\
\hline Met & 2.3 & 1.6 & 1.9 & 0.0 & 0.0 & 0.0 \\
\hline lle & 5.2 & 5.2 & 4.6 & 3.7 & 3.7 & 3.5 \\
\hline Leu & 11.0 & 11.3 & 11.0 & 8.2 & 7.6 & 10.7 \\
\hline Tyr & 2.6 & 2.5 & 2.5 & 4.2 & 3.2 & 2.6 \\
\hline Phe & 3.0 & 3.4 & 3.6 & 3.5 & 4.9 & 3.1 \\
\hline His & 1.9 & 1.8 & 1.9 & 4.0 & 5.0 & 0.2 \\
\hline Lys & 8.5 & 8.6 & 8.3 & 7.0 & 7.5 & 8.0 \\
\hline Arg & 2.6 & 2.6 & 2.7 & 3.1 & 2.9 & 3.5 \\
\hline
\end{tabular}


abomasum sooner. However, proteolysis was observed after $3 \mathrm{~h}$ of digestion (fig. 1), but it concerned only a small part of the protein products leaving the abomasum. Indeed, about $50 \%$ of the ingested $\mathrm{N}$ was evacuated during the first 2.5 postprandial hours as against $60 \%$ during $7 \mathrm{~h}$. As with milk diets, rocket immunoelectrophoresis showed that this proteolysis did not concern $\beta$ lactoglobulin, but particularly involved $\alpha$-lactalbumin (Yvon et al., 1984b), and seemed to slightly modify the amino acid composition of the digesta reaching the abomasum.

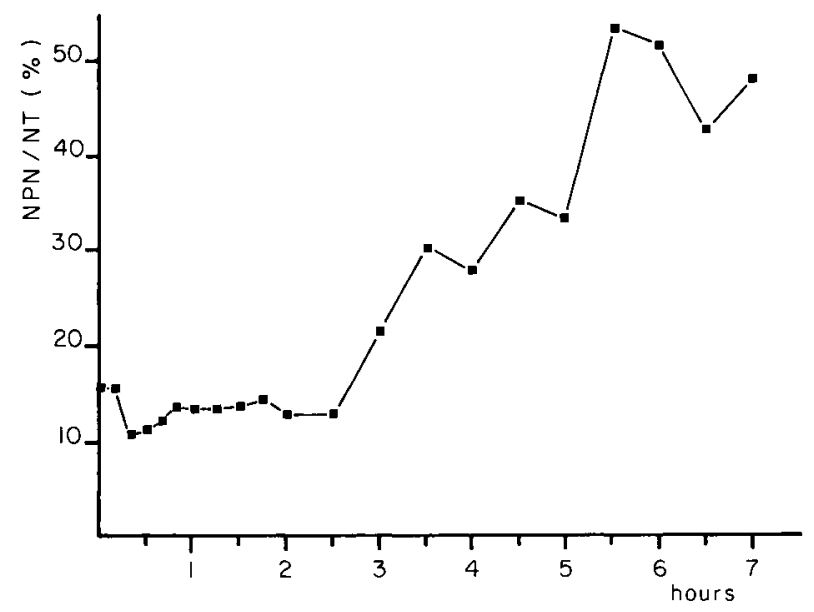

FIG. 1. - Changes in the percentage of NPN relative to total $N$ during digestion time in samples collected after ingestion of the whey diet.

Milk diet digesta. - The amino acid compositions of the sediments obtained with diets A and B (« milk» diets) were similar (table 2). In our experimental conditions, fat did not seem to strongly modify proteolysis.

The amino acid composition of the digesta sediments collected during the first 10 min after the meal was much closer to that of milk than the composition of the sample collected immediately afterwards (Asx : $8.5 \%$; Pro : $9.8 \%$; Cys : $0.9 \%)$. Therefore, coagulation was not complete during the first $10 \mathrm{~min}$; this explains why intact caseins were detected only during this period (Yvon et al., 1984b).

If we look only at the three amino acids (Asx, Pro, Cys) which differed most in casein and whey, we see that after the first $10 \mathrm{~min}$, the composition of the sediments changed with time, from that of whey to that of casein. Therefore, abomasal emptying was more rapid for whey proteins than for casein. These results are in agreement with those reported for abomasal emptying of milk and for diets containing whey protein concentrates (Toullec, Thivend and Mathieu, 1971). The compositions of the supernatants also changed from one time to another, but they were always different (in particular for Glx, Gly and Arg) from those of the digesta obtained before the meal (table 1). 
The composition of the supernatants of the milk-fed calves was closer to that observed in casein-fed than in whey-fed calves. The small peptides produced by milk proteolysis in the abomasum originated from casein rather than from whey proteins. We can suppose that the protein products leaving the abomasum after $7 \mathrm{~h}$ were proteolysed as much as, or more than, the last product collected. As we collected only about $30 \%$ of the ingested $N$ during the first 7 postprandial hours (Pélissier et al., 1983), we can conclude that the major part of the protein products arriving later in the duodenum had an amino acid composition close to that of casein and corresponded mainly to small peptides coming from casein.

Principal component analysis. - The results were confirmed by principal component analysis using the amino acid compositions of the samples. Five different groups of amino acid compositions were evidenced (fig. 2). The sediments were separated into three groups : whey, milk (whole and skim) and

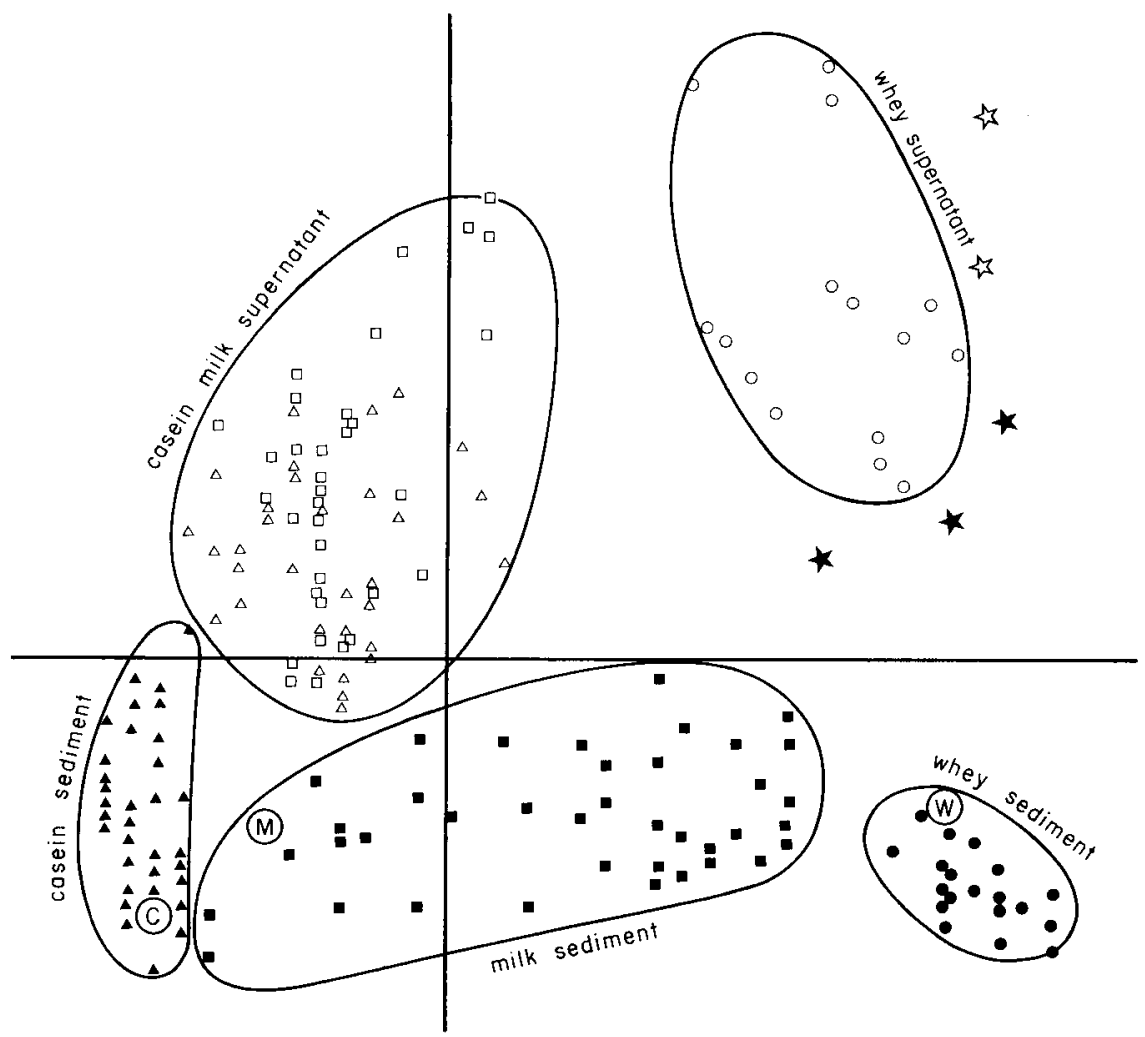

FIG. 2. - Principal component analysis. Comparison of the sediments and supernatants obtained from the digesta leaving the abomasum, using the amino acid compositions as variables. (a) sediments from " milk " diets; (A) sediments from " casein " diets ; ( $\bullet$ ) sediments from " whey " diet ; $(\square)$ supernatants from " milk " diets ; $(\Delta)$ supernatants from " casein " diets ; (O) supernatants from " whey " diet ; (4) supernatants from prefeeding digesta ; $(\star)$ sediments from prefeeding digesta. C : amino acid composition of the "casein " diet; $M$ : amino acid composition of the " milk" diet ; W : amino acid composition of the " whey " diet. 
casein (with or without minerals) diets. The supernatants gave only two groups : whey and the other four diets.

The group corresponding to the sediments of the whey diet digesta was very close to the position of whey protein. The group corresponding to the sediments of the two casein diets was near the position of whole casein, and the group corresponding to the two milk diet sediments was between the former two. The supernatants were different from the sediments. Particularly with the whey diet, their composition was relatively close to that of the prefeeding digesta. This shows that whey proteolysis was not very important and gave only a very few small peptides soluble in $12 \%$ TCA.

The variations with time of the amino acid compositions were not the same in the different groups. In the three groups (whey diet sediment, whey diet supernatant and " casein " diet sediment) no important change was detected between $O$ and $7 \mathrm{~h}$ after the meal. On the contrary, with the "milk " diets, the composition of the sediment changed strongly according to the time after digestion (fig. 3). The composition of the first sample $(0-10 \mathrm{~min})$ was relatively close to that of milk. The composition of the second sample $(10-20 \mathrm{~min})$ was similar to that of whey protein. The composition of the following samples evolved from whey composition to almost that of casein during the 7th hour.

The supernatant compositions obtained with the casein and milk diets were always different from that of whey protein and tended to become more similar to those of caseins as time elapsed (fig. 4).

With all the diets, the most significant modification occurred around $3 \mathrm{~h}$ after the meal. Electrophoresis showed acidic peptides originating from casein proteolysis. The 3-h time also corresponded to the degradation of $\alpha$-lactalbumin. After this time, the amino acid composition of the milk diet digesta changed rapidly. This time corresponded to an acidification of the stomach content which probably induced an increase in the proteolytic activity of pepsin.

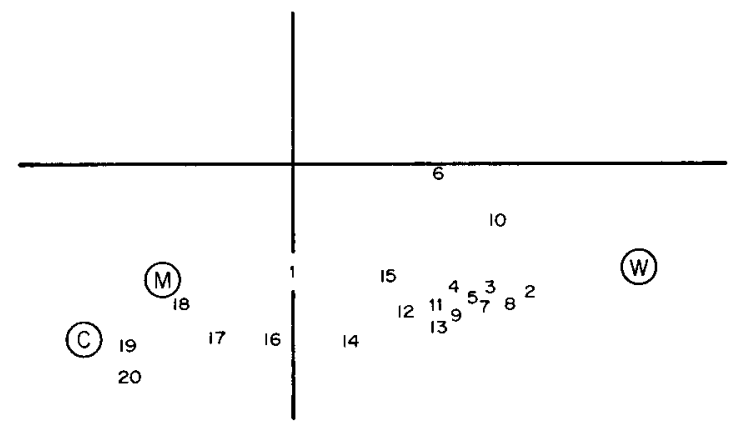

FIG. 3. - Part of the principal component analysis (fig. 2). Changes in the amino acid composition of sediments obtained from digesta leaving the abomasum of calves fed a skim milk diet, using the amino acid compositions as variables. C : amino acid composition of the "casein " diet ; $\mathrm{M}$ : amino acid composition of the " milk " diet; $\mathrm{W}$ : amino acid composition of the " whey 》 diet. The numbers correspond to digestion times: (1): $0-10 \mathrm{~min} ;(2): 10-20 \mathrm{~min} ;(3): 20$ $30 \mathrm{~min} ;(4): 30-40 \mathrm{~min} ;(5): 40-50 \mathrm{~min} ;(6): 50-60 \mathrm{~min} ;(7): 60-75 \mathrm{~min} ;(8): 75-90 \mathrm{~min}$; (9) : 90-105 min ; (10): 105-120 min ; (11): $2 \mathrm{~h}-2 \mathrm{~h} 30 ;(12): 2 \mathrm{~h} 30-3 \mathrm{~h} ;(13): 3 \mathrm{~h}-3 \mathrm{~h} 30$; (14): 3 h 30-4 h; (15) : 4 h-4 h $30 ;(16): 4$ h 30-5 h; (17): 5 h-5 h $30 ;(18): 5$ h $30-6$ h : (19) : 6 h-6 h $30 ;(20): 6$ h $30-7$ h. 


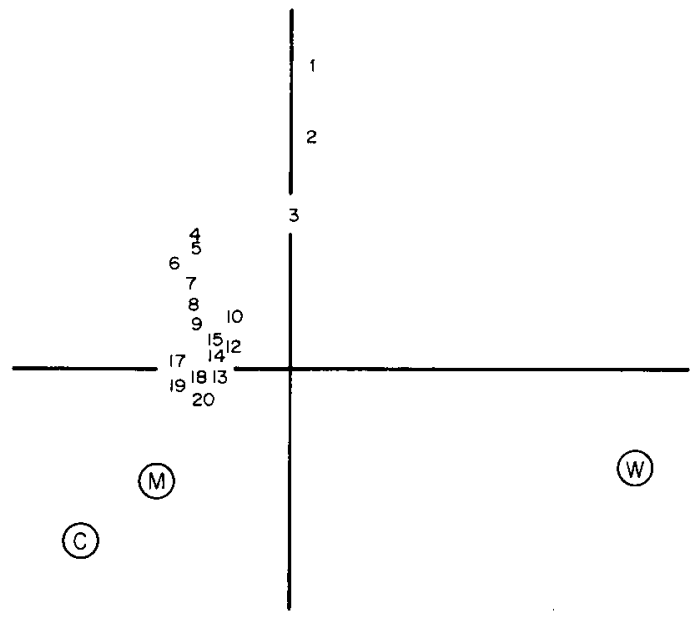

FIG. 4. - Part of the principal component analysis (fig. 2). Changes in the amino acid composition of supernatants obtained from digesta leaving the abomasum of calves fed a skim milk diet, using the amino acid composition as variables. See legend of figure 3.

\section{Conclusion.}

When the calves were given casein, the amino acid composition of abomasal digesta sediment changed little with time after feeding. In contrast, the changes observed in the supernatant compositions suggested rapid abomasal emptying of caseino-macro peptide.

With the whey diet it was not possible to evidence more rapid abomasal hydrolysis or the emptying of any particular whey protein.

With the milk diets, the sediments were milk proteins during the first 10 postprandial minutes and whey proteins immediately after that; they then became progressively more like casein as the time after feeding increased. The supernatant compositions showed that small peptides resulting from abomasal proteolysis originated from casein rather than from whey proteins.

Reçu en juillet 1984. Accepté en janvier 1985.

Résumé. Etude de la digestion in vivo du lait dans la caillette du veau. III. Compositions en acides aminés des digesta.

Des veaux préruminants ont reçu 5 régimes : lait entier, lait écrémé, solution à $3 \%$ de caséine dans l'eau, solution à $3 \%$ de caséine dans un milieu minéral simulant le perméat de lait ultrafiltré et lactosérum. Les digesta quittant la caillette durant les $7 \mathrm{~h}$ qui suivent le repas ont été collectés par fractions. Après précipitation en TCA $12 \%$, les compositions en acides aminés des culots et des surnageants ont été déterminées et comparées par analyse multivariate. 
Les digesta collectés avant le repas ont une composition en acides aminés voisine de celle du suc gastrique. Avec les deux solutions de caséine la composition en acides aminés des culots change peu au cours du temps, contrairement à celle des surnageants dont l'évolution suggère que l'évacuation gastrique du caséino-macro-peptide est très rapide. Avec le lactosérum, il n'est pas possible de détecter une hydrolyse préférentielle, ou une évacuation gastrique plus rapide d'une des protéines ingérées.

Durant les 10 premières minutes suivant l'ingestion de lait entier ou écrémé, la composition en acides aminés des culots est voisine de celle des protéines du lait. Immédiatement après, la composition devient semblable à celle des protéines du lactosérum. Ensuite, la composition évolue pour se rapprocher de plus en plus de celle des caséines. La composition en acides aminés des surnageants ressemble à celle obtenue avec les solutions de caséines. Ceci indique que les petits peptides provenant de la protéolyse dans la caillette proviennent plus des caséines que des protéines du lactosérum.

\section{References}

GUILLOTEAU P., SAUVANT D., PATUREAU-MIRAND P., 1983. Methods of comparing amino acid composition of protein : an application to undigested protein in the preruminant calf. Ann. Nutr. Metab., 27, 457-469.

HILL M. D., 1974. Correspondence analysis : a neglected multivariate method. Appl. Statist., 23. 340-354.

JENNESS R., KOOPS J., 1962. Preparation and properties of a salt solution which simulates milk ultrafiltrate. Neth. Milk Dairy J., 16, 153-164.

JUSTE C., 1982. Endogenous supplies from the digestive secretions in the pig. In LAPLACE J.-P., CORRING T., RÉRAT A. Physiologie digestive chez le porc. I.N.R.A. Publications, 155-173.

MERCIER J.-C., URO J., RIBADEAU DUMAS B., 1972. Structure primaire du caséinomacropeptide de la caséine kB bovine. Eur. J. Biochem., 27, 535-547.

PÉLISSIER J.-P., GUILLOTEAU P., BRULÉ G., TOULLEC R., 1983. Digestion des protéines du lait dans la caillette du veau préruminant. Evacuation gastrique après un repas d'épreuve. Reprod. Nutr. Dévelop., 23, 161-173.

TOULLEC R., THIVEND P., MATHIEU C. M., 1971. Utilisation des protéines du lactosérum par le veau préruminant à l'engrais. I. Vidange stomacale comparée du lait entier et de deux laits de remplacement ne contenant que des protéines de lactosérum comme source de matières azotées. Ann. Biol. anim. Bioch. Biophys., 11, 435-453.

YVON M., PÉLISSIER J.-P., GUILLOTEAU P., TOULLEC R., 1984a. In vivo milk digestion in the calf abomasum. I. Whole casein digestion. Reprod. Nutr. Dévelop., 24, 587-595.

YVON M., VAN HILLE I., PÉLISSIER J.-P., GUILLOTEAU P., TOULLEC R., 1984b. In vivo milk digestion in the calf abomasum. II. Milk and whey proteolysis. Reprod. Nutr. Dévelop., 24, 835-843. 